\title{
Radiation Recall in a Patient with Intrahepatic Cholangiocarcinoma: Case Report and a Literature Review
}

\author{
Waled Bahaj $^{1}$, Lina Ya'qoub ${ }^{1}$, Muhammad Toor ${ }^{2}$, Ashiq Masood ${ }^{2}$ \\ 1. Internal Medicine, University of Missouri-Kansas City School of Medicine, Kansas City, USA 2. Oncology, University \\ of Missouri-Kansas City School of Medicine, Kansas City, USA
}

Corresponding author: Waled Bahaj, bahajw@umkc.edu

\begin{abstract}
Radiation recall dermatitis (RRD) is a rare and poorly understood phenomenon, constituting an inflammatory skin reaction to a previously irradiated area of skin following the administration of certain agents, usually chemotherapy. Our patient developed RRD 66 years after receiving radiation therapy; to the best of our knowledge, this is the longest reported period in the literature. The mainstay of therapy is to withhold the agent that elicited the adverse reaction, followed by symptomatic management. Subjecting patients to further chemotherapy can provoke another episode of RRD. Therefore, clinical judgment in this regard is usually recommended.
\end{abstract}

Categories: Radiation Oncology, Oncology

Keywords: recall dermatitis, rash, gallbladder cancer

\section{Introduction}

Radiation recall dermatitis (RRD) is a rare acute inflammatory reaction of the skin that is limited to previously irradiated skin after the administration of certain agents [1], usually chemotherapy [2]. However, RRD is associated with other medications, including simvastatin, Tamoxifen, and antibiotics [3-4]. It generally appears months to years after radiation therapy, although some cases have been reported after only a few hours or days $[2,5]$. Thus, this phenomenon appears to be independent of the duration between the administration of radiation and the appearance of geographically limited dermatitis. To the best of our knowledge, the longest reported duration between the administration of radiation and drug-induced RRD is 25 years [6]. Here, we present a case of a patient who developed RRD 66 years after receiving radiation therapy.

Received 05/21/2019

Review began 06/14/2019 Review ended 06/19/2019 Published 06/27/2019

๑) Copyright 2019 Bahaj et al. This is an open access article distributed under the terms of the Creative Commons Attribution License CC-BY 3.0., which permits unrestricted use, distribution, and reproduction in any medium, provided the original author and source are credited.

\section{Case Presentation}

A 79-year-old man with a history of right arm soft-tissue tumor of unknown etiology and who had been treated with surgical resection followed by radiation therapy (an unknown dose) to the right arm and shoulder area in 1951, presented at our institution in February 2017 with right-upper-quadrant abdominal pain and weight loss of 10 pounds. Subsequently, he underwent an abdominal ultrasound that revealed a large heterogeneous liver mass measuring $8 \mathrm{~cm} \times 5 \mathrm{~cm} \times 7 \mathrm{~cm}$. An enhancing mass with a necrotic center that involved the right liver lobe (segments 5 and 8 ) and slightly extended into the left hepatic lobe (segment 4), with encasement by at least one portal vein, was demonstrated using magnetic resonance imaging of the abdomen (Figure 1). 


\section{Cureus}

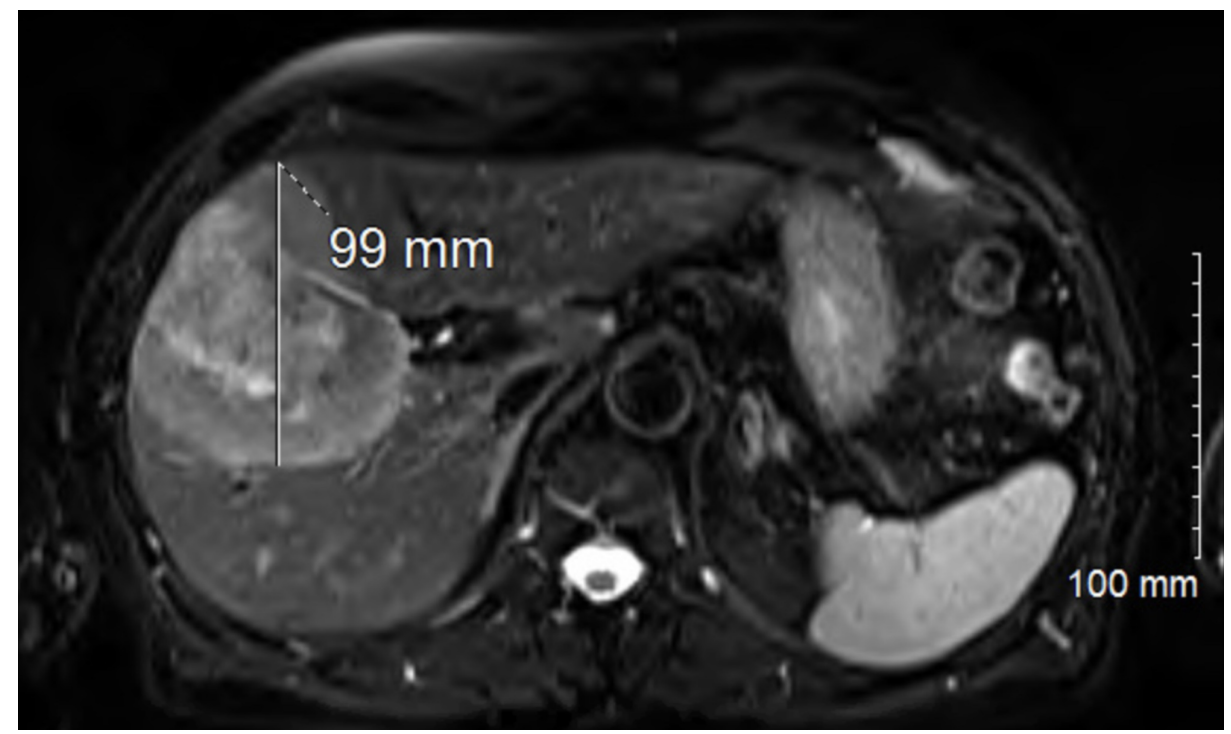

FIGURE 1: MRI abdomen showing enhancing mass with necrotic center

The finding of an ultrasound-guided liver biopsy was consistent with intrahepatic cholangiocarcinoma. After discussions among a multidisciplinary healthcare team, the surgical option was contraindicated. The patient was treated with a combination of simvastatin, tamoxifen $\left(1,000 \mathrm{mg} / \mathrm{m}^{2}\right)$ and cisplatin $\left(25 \mathrm{mg} / \mathrm{m}^{2}\right)$. Four days after cycle one, day eight of gemcitabine, he developed an erythematous, coalescent patchy rash on the right shoulder and arm that extended into the chest wall and was geographically restricted to the site of previous radiation treatment for a soft-tissue tumor (Figure 2).

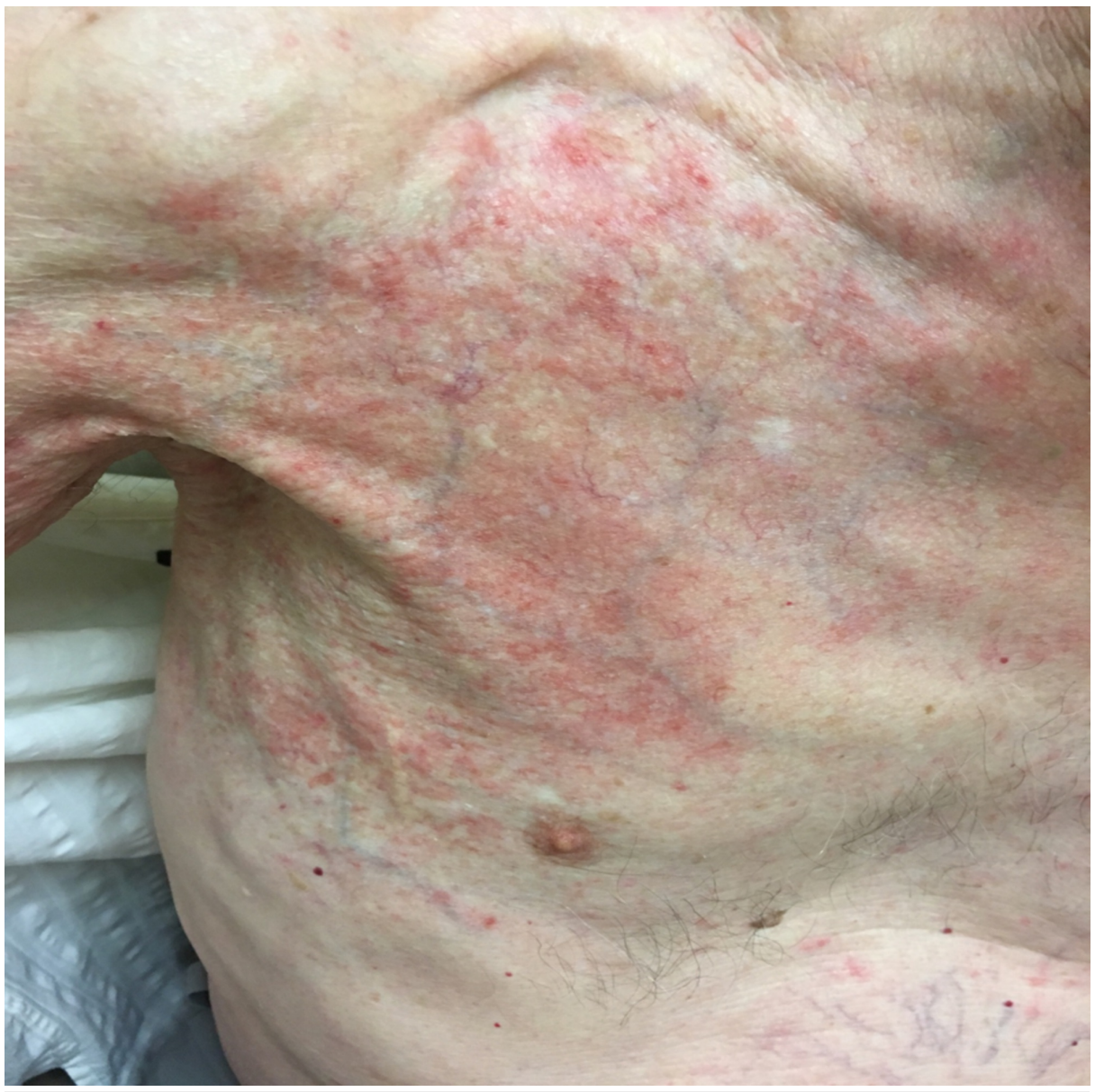

FIGURE 2: Radiation recall dermatitis in the patient's right arm and shoulder, extending to the anterior chest wall. 


\section{Cureus}

The diagnosis was consistent with RRD manifesting 66 years of radiation treatment. He was managed symptomatically with topical triamcinolone and oral antihistamines. The rash improved and completely resolved within three weeks. Upon resolution of dermatitis, the patient was rechallenged with the same dose of gemcitabine/cisplatin, and on this occasion, he tolerated it well.

\section{Discussion}

The pathogenesis of RRD is not fully understood, and different mechanisms have been proposed in this regard. These include local vascular injury with a permeability defect that affects the pharmacokinetics of certain drugs, thereby causing RRD, as well as epithelial stem-cell depletion in the irradiated area, resulting in a recognized reaction in the surviving non-affected cells or mutation in these cells that ultimately led to intolerability of the chemotherapeutic agent. Another suggested theory involves idiosyncratic drug nonimmune reactions [7-8]

Cases of RRD that are characterized by a duration of $\geqslant 1$ year between radiation therapy and the institution of systemic chemotherapy are depicted in Table 1 . Our patient developed RRD 66 years after receiving radiotherapy, which is by far the longest reported period. The time interval between the administration of the agent and the development of RRD also differs between cases; the longest reported interval is seven years [9] while some patients develop a reaction within hours [5]. In the current case, the patient developed RRD 11 days after the administration of gemcitabine and cisplatin. RRD manifests as a maculopapular rash, desquamation, pruritis, swelling, or ulceration of the skin [10]. As was evidenced in our patient, RRD usually appears after the first exposure to the eliciting drug [2]. Adverse reactions are associated with specific medications, such as anthracyclines, taxanes, and antimetabolites like gemcitabine, capecitabine, and pemetrexed [11]. It should be borne in mind that medication type does not correlate with a prolonged interval between radiation exposure and RRD. All reported cases with an interval of $\geqslant 1$ year were demonstrated to have been triggered by different agents. Similarly, gemcitabine has been associated with RRD that occurred at different time intervals [12]. 


\section{Cureus}

\begin{tabular}{|c|c|c|c|c|c|c|}
\hline Author & $\begin{array}{l}\text { Reason for } \\
\text { radiation }\end{array}$ & $\begin{array}{l}\text { Radiation } \\
\text { region }\end{array}$ & Chemotherapy type & $\begin{array}{l}\text { Duration } \\
1^{\mathrm{a}}\end{array}$ & $\begin{array}{l}\text { Duration } \\
2^{b}\end{array}$ & Management \\
\hline $\begin{array}{l}\text { Barlési et al., } \\
2006 \text { [6] }\end{array}$ & $\begin{array}{l}\text { Lung } \\
\text { adenocarcinoma } \\
\text { with breast } \\
\text { metastasis }\end{array}$ & Breast & pemetrexed, prednisone & 25 years & 3 days & $\begin{array}{l}\text { Prednisone }(1 \mathrm{mg} / \mathrm{kg}) \text {. Improvement was } \\
\text { seen in two days. The resolution achieved } \\
\text { in two weeks. }\end{array}$ \\
\hline $\begin{array}{l}\text { Burdon et al., } \\
1978 \text { [16] }\end{array}$ & $\begin{array}{l}\text { Sarcoma of the } \\
\text { palate }\end{array}$ & Unspecified & $\begin{array}{l}\text { doxorubicin, cyclophosphamide, } \\
\text { vincristine sulfate, and high-dose } \\
\text { methotrexate with folinic acid rescue }\end{array}$ & 15 years & 2 weeks & $\begin{array}{l}\text { Drugs were withheld. Topical } \\
\text { amphotericin B and nystatin were applied. } \\
\text { Stomatitis resolved in seven weeks. }\end{array}$ \\
\hline $\begin{array}{l}\text { Taunk et al., } \\
2011 \text { [17] }\end{array}$ & $\begin{array}{l}\text { Early-stage } \\
\text { breast cancer }\end{array}$ & $\begin{array}{l}\text { Whole left } \\
\text { breast }\end{array}$ & rosuvastatin, amlodipine & 5 years & 2 weeks & $\begin{array}{l}\text { Moisturizing lotion was placed on the } \\
\text { affected area, together with } 1 \% \\
\text { hydrocortisone cream. The skin reaction } \\
\text { disappeared at } 21 \text { days }\end{array}$ \\
\hline $\begin{array}{l}\text { Parry et al., } \\
1992 \text { [18] }\end{array}$ & Breast cancer & Breast area & tamoxifen & 2 years & 5 days & $\begin{array}{l}\text { Resolved in two weeks. The patient was } \\
\text { rechallenged with a smaller dose. A mild } \\
\text { rash resulted. }\end{array}$ \\
\hline $\begin{array}{l}\text { Bokemeyer et } \\
\text { al., } 1996 \text { [19] }\end{array}$ & $\begin{array}{l}\text { Advanced breast } \\
\text { cancer }\end{array}$ & $\begin{array}{l}\text { Left breast } \\
\text { and left } \\
\text { chest wall }\end{array}$ & paclitaxel & 2 years & 5 days & Chemotherapy was discontinued. \\
\hline $\begin{array}{l}\text { Marisavljevic } \\
\text { et al., } \\
2005 \text { [20] }\end{array}$ & $\begin{array}{l}\text { Hodgkin's } \\
\text { lymphoma }\end{array}$ & & gemcitabine, decadrone & 2 years & 2 days & $\begin{array}{l}\text { None. The rash resolved in } 10 \text { days. There } \\
\text { was a mild recurrence of it after each the } \\
\text { administration of gemcitabine. }\end{array}$ \\
\hline $\begin{array}{l}\text { Abadir et al., } \\
1995[3]\end{array}$ & $\begin{array}{l}\text { Carcinoma of the } \\
\text { gall bladder }\end{array}$ & Unspecified & simvastatin & 1 year & 2-3 days & Unspecified. \\
\hline
\end{tabular}

TABLE 1: Cases of radiation recall dermatitis characterized by a duration of $\geq 1$ year between
radiation exposure and the institution of systemic chemotherapy

1a: Time between radiation exposure and radiation recall dermatitis

2b: Time between receiving medication and radiation recall dermatitis in a previously irradiated skin area.

Our patient also received cisplatin. Upon reviewing the literature, it was ascertained that only one case of cisplatin-associated RRD has been reported. In that particular case, the patient was started on gemcitabine at the same time. However, in our opinion, it is likely that the adverse reaction was caused by gemcitabine as the latter has been linked to a greater number of RRD cases compared to cisplatin [13].

It is also more probable that high doses of radiation cause RRD. Stelzer et al. evaluated the impact of three different radiation doses (i.e., $8 \mathrm{~Gy}, 20 \mathrm{~Gy}$, and $40 \mathrm{~Gy}$ ) on different Kaposi sarcoma areas in one patient in their study. Bleomycin was seen to cause RRD, but this was only evident in the area that received $40 \mathrm{~Gy}$ [14].

We successfully rechallenged our patient; he received the second cycle of the same dose of gemcitabine/cisplatin after one month of RRD and tolerated it very well. It is not been elucidated whether or not it is acceptable to rechallenge a patient with another cycle of chemotherapy after RRD. Most clinicians tend to avoid doing this to prevent a recurrence. Only a handful of cases have previously been successfully rechallenged, and this has depended on the treatment approach used. Some clinicians prefer to pretreat patients with steroids, while others opt for a dose reduction, mild cases, as well as cases without recurrence, have been reported [6].

The symptomatic management of RRD is the recommended approach. Our patient experienced immediate relief with the use of triamcinolone cream and diphenhydramine while in the clinic. His rash resolved completely within three weeks of the addition of cetirizine. It is also recommended that the causative agent should be withheld or discontinued until healing takes place. Topical or systemic steroids, nonsteroidal antiinflammatory medications, and antihistamines have been used for symptomatic relief, and healing is often achieved within two weeks [1-2]. Surgical intervention with wound excision and debridement is the last resort if complicated reactions persist despite the proposed management [9].

Radiosensitization is more common than RRD. It is important to distinguish between these two entities, and this can be achieved by considering the timing. Camidge et al. suggest that an adverse skin reaction to 
radiation with the simultaneous administration of chemotherapy, and/or within a seven-day timeframe, should be viewed as radiosensitization rather than RRD [2]. Interestingly, trials in which the administration of chemotherapy was deferred for a few days following radiation exposure resulted in a dramatic reduction in the skin reaction [15].

\section{Conclusions}

In summary, following the exposure to the provoking drug, RRD usually appears in a previously irradiated skin area. Our case highlights that RRD can occur decades after initial exposure to radiation and clinicians should be aware of this when treating patients presenting with skin changes in the same geographic area of radiation. Discontinuation of the offending agent and symptomatic management are the recommended approaches of treating RRD.

\section{Additional Information \\ Disclosures}

Human subjects: Consent was obtained by all participants in this study. Conflicts of interest: In compliance with the ICMJE uniform disclosure form, all authors declare the following: Payment/services info: All authors have declared that no financial support was received from any organization for the submitted work. Financial relationships: All authors have declared that they have no financial relationships at present or within the previous three years with any organizations that might have an interest in the submitted work. Other relationships: All authors have declared that there are no other relationships or activities that could appear to have influenced the submitted work.

\section{References}

1. Azria D, Magné N, Zouhair A, et al.: Radiation recall: a well recognized but neglected phenomenon . Cancer Treat Rev. 2005, 31:555-70. 10.1016/j.ctrv.2005.07.008

2. Camidge R, Price A: Characterizing the phenomenon of radiation recall dermatitis . Radiother Oncol. 2001, 59:237-45. 10.1016/S0167-8140(01)00328-0

3. Abadir R, Liebmann J: Radiation reaction recall following simvastatin therapy: a new observation . Clin Oncol (R Coll Radiol). 1995, 7:325-6. 10.1016/S0936-6555(05)80545-X

4. Extermann M, Vogt N, Forni M, Dayer P: Radiation recall in a patient with breast cancer treated for tuberculosis. Eur J Clin Pharmacol. 1995, 48:77-8.

5. Nemechek PM, Corder MC: Radiation recall associated with vinblastine in a patient treated for Kaposi sarcoma related to acquired immune deficiency syndrome. Cancer. 1992, 70:1605-6.

6. Barlési F, Tummino C, Tasei AM, Astoul P: Unsuccessful rechallenge with pemetrexed after a previous radiation recall dermatitis. Lung Cancer. 2006, 54:423-5. 10.1016/j.lungcan.2006.06.021

7. Yeo W, Johnson PJ: Radiation-recall skin disorders associated with the use of antineoplastic drugs. Pathogenesis, prevalence, and management. Am J Clin Dermatol. 2000, 1:113-6. 10.2165/00128071200001020-00006

8. Wintroub BU, Stern R: Cutaneous drug reactions: pathogenesis and clinical classification. J Am Acad Dermatol. 1985, 13:167-79. 10.1016/S0190-9622(85)70156-9

9. Mayer EG, Poulter CA, Aristizabal SA: Complications of irradiation related to apparent drug potentiation by adriamycin. Int J Radiat Oncol Biol Phys. 1976, 1: 1179-88. 10.1016/0360-3016(76)90091-2

10. Bray FN, Simmons BJ, Wolfson AH, Nouri K: Acute and chronic cutaneous reactions to ionizing radiation therapy. Dermatol Ther (Heidelb). 2016, 6:185-206. Accessed: June 26, 2019: 10.1007/s13555-016-0120-y

11. Burris HA, Hurtig J: Radiation recall with anticancer agents. Oncologist. 2010, 15:1227-37. 10.1634/theoncologist.2009-0090

12. Fakih MG: Gemcitabine-induced rectus abdominus radiation recall . JOP. 2006, 7:306-10. Accessed: June 26, 2019: https://www.ncbi.nlm.nih.gov/pubmed/16685112.

13. Alderman C, Sargant N, Simpson S, Roy A, Milne A: Radiation recall following cisplatin chemotherapy. Br J Haematol. 2013, 163:421. 10.1111/bjh.12538

14. Stelzer KJ, Griffin TW, Koh WJ: Radiation recall skin toxicity with bleomycin in a patient with Kaposi sarcoma related to acquired immune deficiency syndrome. Cancer. 1993, 71:1322-5. 10.1002/10970142(19930215)71:4<1322::aid-cncr2820710425>3.0.c0;2-z

15. Aristizabal SA, Miller RC, Schlichtemeier AL, Jones SE, Boone ML: Adriamycin-irradiation cutaneous complications. Int J Radiat Oncol Biol Phys. 1977, 2:325-31.

16. Burdon J, Bell R, Sullivan J, Henderson M: Adriamycin-induced recall phenomenon 15 years after radiotherapy. JAMA. 1978, 239:931. 10.1001/jama.1978.03280370027017

17. Taunk NK, Haffty BG, Goyal S: Radiation recall 5 years after whole-breast irradiation for early-stage breast cancer secondary to initiation of rosuvastatin and amlodipine. J Clin Oncol. 2011, 29:e661-3. 10.1200/JCO.2011.35.7202

18. Parry BR: Radiation recall induced by tamoxifen. Lancet. 1992, 340:49. 10.1016/0140-6736(92)92460-W

19. Bokemeyer C, Lampe C, Heneka M, Schabet M, Bamberg M, Kanz L: Paclitaxel-induced radiation recall dermatitis. Ann Oncol. 1996, 7:755-6. 10.1093/oxfordjournals.annonc.a010730

20. Marisavljević D, Ristić B, Hajder J: Gemcitabine-induced radiation recall dermatitis in a patient with resistant Hodgkin lymphoma. Am J Hematol. 2005, 80:91. 10.1002/ajh.20379 